editions is no longer available. However, the book is small enough to take along in all but the most tightly packed backpack.

A 5-year gap since the previous edition means that a lot of information has been updated, making this a worthwhile purchase for readers with the older editions. In addition to having the bulk of its text updated, this edition now includes chapters on relevant legal issues as well as children at altitude.

Considering its modest size, this book does an excellent job of covering all the necessary sections and it leaves few topics uncovered. Although some of the chapters may be quite short and even superficial, this is more than compensated for by an extensive bibliography at the end of each chapter.

The volume includes a small collection of color photographs that illustrate life and medicine at high altitude. They are a pleasant addition to the text; however, they are not especially relevant to the text or the problems covered within.

Overall, this is a well-written and well-organized book covering the majority of topics important to medicine at high altitude. It presents the information in a clear and easy-to-read format. In fact, the book can be easily read from cover to cover, giving the neophyte a rapid introduction to this topic. The book will make an equally worthwhile addition to the library of the high-altitude traveler and both medical and nonmedical trek leaders.

Gerald Dubowitz, MB, ChB San Francisco, CA, USA

\author{
Between A Rock And A Hard Place \\ Aron Ralston \\ New York, NY: Atria Books (Simon \& Schuster), \\ 2004 \\ US \$26.00, 354 pages, hardcover
}

The tale of this young man's ordeal is legendary, even though it occurred not too long ago in April 2003. Who is not familiar with the accident that befell Aron Ralston in Blue John Canyon, where he set loose an 800-pound boulder that trapped his arm and nearly cost him his life? Who is not aware that he mustered the courage and determination to amputate his own hand in order to free himself and live to tell the story? Which of us who know his story has not asked him- or herself, "Could I do the same thing? Could I cut off my arm to save my life?"

It was with maximal anticipation that I sat in the front row at the Wilderness Medical Society Annual Meeting in Snowmass, CO, to listen to Aron tell his tale. And tell it he did. I have listened to world-class mountain climbers describe harrowing adventures on the highest peaks, to divers relate sagas of shark attacks and abandonment at sea, and to firefighters relive miracles that saved them in the belly of the beast, but I have never been riveted to a speaker like I was to Aron Ralston. He edited his tale masterfully so that we could share first in his fear, fatigue, thirst, and demise and then weep tears of joy at his rescue and salvation. His narration was wilderness medicine to the maximum. If anyone in the audience ever goes anywhere without first letting someone know his or her destination, I will be astounded.

I spoke with Aron a couple of times after his presentation, because he also attended the Wilderness Medical Society meeting to support his medical education as a search-and-rescue team member. My conversations with him left me with the impression of a man who is still processing what all of this means. By his description, he came to this harrowing crossroads because of a confluence of youthful exuberance, passion for the outdoors, determination, spontaneous adventure seeking, athleticism, poor planning, remarkable family and friends, and a profound will to live. In the process, he has made a name for himself but at the expense of a permanent physical handicap and bouts of despondency. It is too early to tell, but I am hopeful that he will always appreciate the gift he has acquired to offer sound advice and hope to those who will most benefit from his ministry.

Without letting anyone know his destination, Aron had embarked from Aspen, CO, on an outing as a solo canyoneer in Utah. He was an experienced climber but, as he points out often in the book, prone to putting himself into dangerous situations. He accidentally dislodged a boulder, which fell and pinned his arm to a canyon wall. He then spent 5 nights in the canyon, deteriorating physically but remarkably holding himself together mentally. He recounts in detail his thought processes and activities as he consumed a precious 22 ounces of water and 2 desiccated burritos, then went without food and water. To try to stay warm at night, he wrapped his limbs with a rope and kept his head in a bag. His situation prevented sleep for 120 consecutive hours, and he had no choice but to drink his own urine. Certain of his impending death, he scratched his name, birth date, and "RIP" on the sandstone wall. For posterity, he recorded his condition and thoughts daily on a video camera. On the sixth day, he managed to free himself by the only means available: he fractured both bones in his forearm and then completed an amputation of his hand and wrist with a barely adequate multitool. To complete his survival journey, he rappelled a 60-foot rock wall and walked for several hours with his arm wrapped in a CamelBak, which was then secured to his chest. When 
we read about how he drank foul water from a mud hole, we lick our lips. When we read of his discovery and helicopter flight to the hospital, our relief is genuine.

Even though I was quite familiar with the events, I was drawn into this book quickly. For those who have been in precarious situations and for armchair enthusiasts alike, it is easy to project oneself trapped in Aron's dilemma. His description of what he was thinking is perfectly juxtaposed against the deterioration of his body. We witness him become philosophical, but not spiritual, in a very honest rendition of what became important to him at the time. His love for his family may have been his salvation. We all know what happens in the end. The strength of this story is in the journey, not in the destination.

I read an interview with Aron in Publishers Weekly in which he describes how his editor helped him tone down what was deemed to be "over the top." His editor should have done more to help Aron de-emphasize his "background" noncritical adventures and quest for recreational adventure and achievement and instead focus on his qualities that are so brilliantly written as he describes his ordeal in the canyon. Midway through the volume, I felt that I was reading 2 books - 1 describing the entrapment and 1 describing Aron's less profound adventures and misadventures. The 2 story lines are both stylistically and emotionally quite different and left me with 2 different impressions. Eventually, I became riveted to the entrapment and bypassed what at times seemed trivial and less worthy of so many pages. Furthermore, I found myself growing judgmental after Aron describes episodes of jumping into the Colorado River and nearly drowning, having a near-death experience in an avalanche, becoming trapped alone on a mountainside in a thunderstorm, and so on. It is as if he is building up to the "big one." These tales are the way that he explains his nature, but they speak more of luck than of character building. Having met the man in person, I feel more comfortable with my impression of him from that particular vantage point than from his penned self-analyses. If he were in any way reckless before, he does not seem reckless now.

This book is about more than making choices; it is about the will to live. Aron's hand was likely ruined the moment it was crushed. If he had been with a companion and if a rescue had been mounted as soon as possible, it still would have taken many hours to free him and, given the forces involved, the outcome would have likely been the same, perhaps without the dehydration and the postamputation infection. What makes this situation different is that he went through the experience alone and defied the odds that loomed against normal human physiology and endurance.
One of the tests of effective literature is how often you find yourself reminiscing or even imagining yourself to be a character. Weeks after reading Aron's book, I find myself aware of the taste of water and savoring the precious fluid as I gulp it down, rather than taking it for granted. When I cared for a teenager recently with a fracture dislocation of his ankle, I pictured the same injury in a solo hiker 50 miles into the backcountry. What would I do? My first-aid kit has been reconsidered and revised.

Aron informed me that he would like to pursue the career of an adventure writer. He certainly has written a very good first book. For him, there should be no issues of survivor's guilt. His actions cost him his hand but will undoubtedly save the hands, lives, and perhaps even souls of others. I wish him every success as an author, but for God's sake, Aron, be careful. I truly hope that he makes a swift transition to personal tales devoid of catastrophe or becomes like John Krakauer, who can spin a story from history and the experiences of others. Aron has already done us a huge service by sharing in a very straightforward manner what it is like to face near-certain death yet conquer your fears and move on. I will follow his career with great interest.

Paul S. Auerbach, MD Los Altos, CA, USA

\section{Edible and Poisonous Mushrooms of the World}

Ian R. Hall, Steven L. Stevenson, Peter K. Buchanan,

Wang Yun, and Anthony L. J. Cole

Portland, OR: Timber Press Inc, 2003

US \$39.95, 371 pages, hardcover

This book covers a broad spectrum of what is known about edible and poisonous mushrooms. However, not immediately apparent from the title is that this is an Australasian guide to mushrooms (expanded to include Asia). Although inclusive of a lot of information useful to a European or North American readership, this is not its area of major focus. Along these lines, it opens with a word of warning about confusing edible and poisonous mushrooms, written in English and translated into 5 Asian languages and, intriguingly, Maori.

The text is divided into sections that include cultivation, collecting, a listing of wild mushrooms, appendices, and a detailed bibliography. Each section is well written and extensively illustrated with color photos.

The purpose of the book is mostly educational. It seeks to serve as a reference text and not to be just a field guide. It includes a detailed presentation of many aspects of the mushroom, from commercial farming to 